\title{
Crisis Communication in Romania and Social Media Influencers and Followers. Case Study: Patient's Death at the Sanador Hospital
}

\author{
Raluca BARBU \\ Department of Journalism \\ Faculty of Journalism and Communication Studies \\ University of Bucharest, Romania \\ E-mail: ralucabarbu0502@yahoo.com

\section{Prof. Camelia CMECIU, PhD} \\ Department of Journalism \\ Faculty of Journalism and Communication Studies \\ University of Bucharest, Romania \\ E-mail: camelia.cmeciu@fjsc.ro
}

\begin{abstract}
Social media urge researchers on crisis communication to go beyond an agency approach. Multiple voices could be heard in the online environment when a crisis situation occurs especially when an organization does not engage online. Using a collaborative approach, this paper will provide an analysis of the Sanador Hospital crisis which took place in October 2018 when a child died after an inguinal hernia surgery. The social-mediated crisis communication (SMCC) model constitutes our theoretical framework. Since online users are not passive consumers of online information, but seek emotional support, we will provide an insight into the online users' emotional responses. This study has a threefold purpose: (1) to identify the roles the Romanian influencers and online users played throughout this crisis at the Sanador Hospital; (2) to determine how key publics framed this crisis; (3) to identify the types of emotions embedded in the influencers' posts and followers' comments. The main findings revealed that this social-mediated crisis also brought
\end{abstract}


forth online users' own interests through a re-framing of the influencers' posts and that besides contempt and disgust, as the most salient emotional responses, anger toward other online users was also present, thus highlighting that the online environment during crisis situations may trigger online users' aggressive self-involvement.

Keywords: Social-mediated crisis communication (SMCC) model; QDA miner; Romania; influencers; Followers.

\section{Introduction}

In 2010, in the chapter "Future directions of crisis communication research: Emotions in crisis - the next frontier", Yan Jin and Augustine Pang (2010) highlighted the important role that publics play throughout a crisis situation. Nowadays, after nine years, with the advent of social media, a crisis situation cannot be tackled upon using only a single organization as the sole source of information. Twofold changes have brought social media to the landscape of crisis communication (Austin and Jin, 2017; Jin, Liu and Austin, 2014): on the one hand, social media as a source of an organizational crisis, or what Coombs and Holladay (2012) label a 'paracrisis,' and on the other hand, social media as a vehicle of negative opinion sharing, but also of emotional venting and /or seeking emotional support.

This was the case of the crisis situation at the Sanador Hospital, a private hospital in Romania: Facebook turned into a place where a cluster of negative emotions towards Sanador started to grow after the death of a baby boy. On October 21, 2018 at 00:15, a one year and 10 months boy died several hours after he went through an inguinal hernia surgery. ${ }^{1}$ Later that day, the boy suffered from cardio-respiratory arrest and despite all the cardiopulmonary resuscitation maneuvers, he died. The prosecutors opened a criminal case for manslaughter. ${ }^{2}$ Firstly, Sanador hospital declared that they would not provide any details about the case since this death had unknown causes. On October 22, the representatives of the hospital stated in a press release that all medical procedures were respected. ${ }^{3}$ Two days later, the

1 Reacția SANADOR, după ce un copil a murit în spitalul său în urma unei operații de rutină, https://adevarul.ro/news/eveniment/reactia-sanador-copil-spitalul-urma-operatii-simple-1_5bcd 9f28df52022f75bfc1ab/index.html, accessed April 18, 2019.

216 ore între viață și moarte. Ce s-a întâmplat în ziua în care băiețelul operat la Spitalul Sanador a murit, https://www.libertatea.ro/stiri/16-ore-intre-viata-si-moarte-ce-s-intamplat-ziua-care-bai etelul-operat-la-spitalul-sanador-murit-2518849, accessed April 18, 2019.

3 Reacția SANADOR, după ce un copil a murit în spitalul său în urma unei operații de rutină, https://adevarul.ro/news/eveniment/reactia-sanador-copil-spitalul-urma-operatii-simple-1_5b cd9f28df52022f75bfc1ab/index.html, accessed April 18, 2019. 
autopsy revealed that the boy died because of a hemorrhagic shock, produced by internal bleeding. On October 25, the College of Physicians made public the results of the investigation (the inadequacy of the monitoring vital parameters) and four days after the boy's death, a press conference was held and the surgeon declared that all the medical procedures were strictly followed.

The following days, third party, "any groups or individuals outside the organization, including other publics and the media" (Jin et al., 2014, 80), became very active on social media. Various Romanian influencers uploaded angry posts on their private Facebook pages, expressing their revolt against the Sanador hospital and their compassion for the family. Romanian citizens commented on these posts and, at the same time, provided comments to two Facebook posts of the Sanador hospital that were uploaded several days before the child's death.

On March 25, 2019 the College of Physicians found the six doctors who took part in the surgery guilty, this implying that they could not get a promotion in the following six months. ${ }^{4}$ One day later, the Sanador hospital announced in a press release that the six doctors were dismissed, that the hospital was open to further investigations, and that the activity of the pediatric ward was taking place normally. ${ }^{5}$

Throughout all this time, the Sanador Hospital issued only two press releases and did not communicate on social media platforms. This is the reason why our analysis goes beyond an agency approach. Adopting a collaborative approach, our analysis will focus on the social media posts of four Romanian influencers (Dan Negru, Corina Băcanu Călărașu, Corina Vințan, Oana Dobre Dimofte) and on the comments provided by online users to these posts. Freberg et al. study $(2011,91)$ on a social media influencer prototype revealed that social media influencers are seen as "verbal, smart, ambitious, productive, and poised." Balaban and Mustățea $(2019,41)$ showed that Romanian social media influencers could be associated with four important elements of the perceived credibility: attractiveness, trustworthy, expertise, and similarity. All four Romanian influencers made a post criticizing the unprofessional press release issued by the Sanador hospital and all of them fit into the Romanian social influencer prototype as communication experts: Dan Negru, a well-known TV presenter (141,269 Facebook followers); Corina Băcanu Călărașu, influencer and communication specialist (58,025 followers); Oana Dobre Dimofte (journalist); Corina Vințan (Founder \& Managing Director at Links Associates).

4 Cazul Sanador. Sorina Pintea: Votul de blam este o sancțiune foarte gravă pentru un medic, https://www.realitatea.net/cazul-sanador-sorina-pintea-votul-de-blam-este-o-sanc-iune-foartegrava-pentru-un-medic_2185449.html, accessed April 18, 2019.

5 Sanador i-a concediat pe medicii sancționați după moartea unui copil, https://www.digi24.ro/sti ri/actualitate/sanatate/sanador-i-a-concediat-pe-medicii-sanctionati-1104026, accessed April 28, 2019. 
The collaborative approach adopted for this study goes hand in hand with the social-mediated crisis communication model (SMCC, Austin et al., 2012; Liu et al., 2012) since the crisis information source comes from third party endorsers whose role is to "shape audience attitudes through blogs, tweets, and the use of other social media" (Freberg et al., 2011, 90). Since publics use social media during crises because it provides emotional venting and/or emotional support, this study has a threefold purpose: (1) to identify the roles the Romanian influencers and online users played throughout this crisis at the Sanador Hospital; (2) to determine how key publics framed this crisis; (3) to identify the types of emotions embedded in the influencers' posts and followers' comments.

\section{Theoretical framework}

Developed in 2012 by Liu et al. to address the impact of social media on crisis communication, the social-mediated crisis communication (SMCC) model has served, so far as, as the first theoretical framework to describe "the relationships between organizations, online and offline publics, social media, traditional media, and word-of-mouth communication before, during and after crises" (Austin, Jin, 2017, 170). In the literature review provided by Cheng and Cameron (2017), it was shown that the SMCC model has been used in more than 60 studies published in academic journals indexed in Social Sciences Citation Index. Despite this extended usage of the SMCC model, Cheng and Cameron $(2017,15)$ highlighted several weaknesses: a narrow content of research perspectives and sampling frames, a lack of emphasis on crisis phases, a biased measure of crisis communication effectiveness, or a westernization of the SMCC research. By laying an emphasis on a national case study, we intend to address the last research gap mentioned by Cheng and Cameron, namely our intention is to "de-westernize the SMCC research in a global context" (17).

Despite its weaknesses, the SMCC model provides valuable insights into the key publics involved in a crisis and into the publics' emotional responses as engagement behaviors.

Besides the social media inactives, two main categories of key publics are identified in the SMCC model (Austin et al., 2012; Liu et al., 2012; Jin et al., 2014; Austin, Jin, 2017):

- influential social media creators - who generate and post crisis information online;

- social media followers - who "consume this information from social media creators and also share this information both on and offline" (Austin, Jin, 2017, 171).

In their study on the Lancôme regenerative crisis, Mak and Song (2019) refined the SMCC model in terms of the types of publics to be taken into account while 
discussing crisis communication and social media. The two authors considered that the influential social media creators should not be limited to journalists of traditional media as Austin et al. (2012) claimed. Mak and Song (2019) consider that organizations should understand various features of different creators and "identify the types of creators participating alongside the crisis cycle" (13) and this is the reason for which a sub-class of influential social media creators should be considered, namely self-involved social media influencers. This type of an influencer is not restricted to journalists, it may include an organization, a politician, or a celebrity, and its main characteristics are (Mak, Song, 2019, 13): a) he/ she does not discuss the crisis itself but he/ she has a clear standpoint for or against the organization; b) he/ she engages in a crisis by picking opportune time and sensational rhetoric for their own purposes; c) he/ she usually engages in a crisis for empathy in dialogical communication.

Most online users are not passive consumers of information, they read, share, even re-frame the information posted, and seek for emotional support. Throughout a crisis, emotions should be associated with attribution since people try to attribute an organization's responsibility to the crisis (Coombs, 2007). Starting from Choi and Lin's (2009) typology of emotions (attribution-independent emotions versus attribution-dependent emotions), Jin et al. (2014) brought a thorough insight into these two types of emotions. Jin et al. $(2014,81)$ mentioned that it is important to determine the crisis origin in order to understand how attribution of emotions works: "External crisis origin links to low organizational responsibility attribution, whereas internal crisis origin links to high organizational responsibility attribution." Thus, various studies (Jin et al., 2014; Mak, Song, 2019, etc.) have shown that:

- publics may feel more attribution-independent emotions (confusion, shame, and sympathy) when the crisis origin is external;

- publics may feel more attribution-dependent emotions (anger, surprise, worry, fear, contempt, alert, disgust, and relief) when the crisis origin is internal.

\section{Methodology}

\section{Research design}

For the qualitative and quantitative content analysis of the Facebook posts and comments, we used the QDA miner 5 software, we text-mined the third parties' posts and comments by means of the code systems, crafted from the SMCC typology of key publics and types of emotions. This study addresses two research questions:

RQ1: What types of key publics serving as third party in the Sanador Hospital crisis can be observed, with reference to the SMCC model?

RQ2: How do social media publics emotionally generate and/or consume the Sanador Hospital crisis information? 
The data included four Facebook posts of the four public persons in Romania and the 179 comments provided by online users. We coded all posts and comments taking into account the following coding procedure. Since online users as Facebook commenters are also important because they may re-frame the messages provided in posts by social media creators, we consider that self-involvement should apply to followers as well. Thus to determine the types of key publics involved in the Sanador Hospital crisis, the following categories were included in the codebook:

A. Social media creators with two subcategories:

- influential social media creator - an online user who generates and posts crisis information related to the Sanador Hospital crisis;

- self-involved social media influencer - an online user who does not discuss the Sanador Hospital, but has a clear standpoint for or against the Sanador Hospital in his/ her posts.

B. Social media followers with two subcategories:

- social media follower - an online user who consumes the information posted by social media creators about the Sanador Hospital crisis. He/ she provides comments to the Facebook posts by making reference to the respective crisis;

- self-involved social media follower - an online user who consumes the information posted by social media creators or influencers, but does not make reference to the Sanador Hospital crisis.

To reveal the emotional responses expressed by the four Romanian influencers and online users, all posts and comments were coded for the two types of emotions:

- attribution-independent emotions (confusion, shame, and sympathy);

- attribution-dependent emotions (anger, surprise, worry, fear, contempt, alert, disgust, and relief).

Taking into account that the crisis origin at the Sanador Hospital is internal (the doctors were found guilty of the child's death), we expect to find more attributiondependent emotions. But since the crisis outcome is the death of a child, we also expect to find sympathy as a salient emotion as well. An inductive analysis of $10 \%$ of the online users' comments provided various themes associated to their emotional responses (posts and comments). For example, the coding scheme included emotions towards Sanador (tow Sanador), emotions towards the doctors responsible for the child's death (tow doctors - CD), emotions towards the Romanian medical system (tow Ro medical system); emotions towards the Romanian society (tow Ro society); emotions towards online users (tow online user) and emotions towards mass-media (tow mass-media).

The intercoder reliability analysis for emotions revealed the following coefficients: for emotions toward Sanador (contempt -0.81 ; disgust -0.74 ; anger -0.80 ; 
fear -0.82 ); emotions toward doctors (contempt -0.88 ; disgust -0.80 ; anger 0.81 ); emotions toward the Romanian medical system (contempt -0.90 ; disgust - 0.76); emotions toward the Romanian society (contempt -0.90 ; disgust -0.88 ); emotions toward online users (anger -0.91 ; contempt -0.77 ; disgust -0.81 ); emotions toward the victims (sympathy -0.96 ).

\section{Results}

The online environment has provided the place where everybody may express his/ her own opinion regarding an issue. This is also the case of the crisis situation at the Sanador Hospital. Besides the four influencers (Dan Negru, Corina Băcanu Călărașu, Corina Vințan, Oana Dobre Dimofte) who may be considered content creators, online users who posted comments may also turn into secondary content generators since their comments triggered various thematic strands related to the crisis. Thus we also coded online users who posted comments either as social media followers (providing comments embedding crisis information related to the Sanador Hospital crisis) or as self-involved social media followers (providing comments embedding information not related to the Sanador Hospital, but having a clear standpoint for or against this hospital). At the same time, each online user can act either as an influential social media creator or as a self-involved social media influencer when he/ she makes Facebook posts, or either as a social media follower or as a self-involved social media follower when he/ she makes Facebook comments. Table 1 illustrates the number of instances the four public persons acted as influential social media creators or as self-involved social media influencers and the number of those instances the other online users acted as social media followers or as self-involved social media followers. As observed, both categories framed themselves more as self-involved users.

Table 1. Types of key publics - Sanador crisis communication

\begin{tabular}{lcc}
\hline \multicolumn{1}{c}{ Types of key publics } & $\begin{array}{c}\text { Public persons - } \\
\text { initiators of Facebook posts } \\
\text { (no. of instances) }\end{array}$ & $\begin{array}{c}\text { Online users - } \\
\text { as commenters } \\
\text { (no. of instances) }\end{array}$ \\
\hline Influential social media creators & 4 & \\
Self-involved social media influencer & 6 & 32 \\
Social media followers & & 76 \\
Self-involved social media followers & & \\
\hline
\end{tabular}

The four public persons provided in their posts information about the improper crisis communication management delivered by the Sanador Hospital in their press release. As influential social media creators, they criticized the lack of professionalism of the public relations department which did not express any sympathy with the family and the scandalous remark of the doctor who performed the sur- 
gery: "Finally, dear Sanador, stupidity pays off. It is outrageous what the surgeon declared: «We were more attentive here than in other public hospitals.» Really?"6

Despite their criticism closely related to the communication aspect of this crisis situation, all four public persons framed themselves as self-involved social media influencers by:

- mentioning their personal experiences with this hospital (the mother's death at Sanador);

- bringing forth intertextual elements (the mention of Dr. House's sympathetic gesture towards a mother whose child just died);

- emphasizing their revolt against the passive Romanian society who does not seem willing to protest against a decaying medical system.

In 32 instances the online users who posted comments following the trend imposed by the public persons, namely, to criticize the communication style of the hospital, became social media followers. In 76 instances, self-involvement seemed to prevail. Various strands of discussion could be identified:

- online users' unfortunate personal experiences at the Sanador Hospital;

- comparisons between private and public hospitals;

- a decaying Romanian medical system;

- criticism towards 'know-it-all Facebook specialists.'

Facebook online users (both the four public persons as influencers - Table 2 and the online users as commenters - Table 3) tended to express more negative emotions than positive emotions. In the four Facebook posts, there were only 3 instances of expressing sympathy towards the family who lost their child. As observed in Table II, contempt (9) and disgust (5) prevail: for example, contempt (7) regarding Sanador for their lack of emotional involvement in the tragedy and disgust (3) towards an inefficient Romanian medical system.

Emotions toward Sanador were strong and sustained in the four Facebook posts. The influencers' contempt inducing position was directed toward the hospital's lack of sympathy. All four influencers clearly stated that their criticism was targeted to the crisis communication management of the hospital. Framing themselves as communication specialists could justify their emotional engagement in judging the Sanador Hospital.

As Miceli and Castelfranchi (2018) mention, disgust, unlike contempt, implies fear-driven avoidance. Although disgust was not as frequently used as contempt, this negative emotion is more present in Oana Dobre Dimofte's post and it was more targeted toward the collapsing Romanian medical system and the indifferent

6 Our translation, https://www.facebook.com/corina.bacanu/posts/10156203646277875, accessed March 3, 2019. 
Table 2. Frequencies of the influencers' emotions on Facebook (generated by QDA miner 5.0)

\begin{tabular}{llrr}
\hline \multicolumn{2}{c}{ Emotions } & Frequency & \multicolumn{1}{c}{$\%$} \\
\hline & Fear & 2 & $5.10 \%$ \\
& Contempt tow Sanador & 7 & $17.90 \%$ \\
& Contempt tow doctors - CD & 1 & $2.60 \%$ \\
\cline { 2 - 4 } Attribution-dependent emotions & Contempt tow Ro medical system & 1 & $2.60 \%$ \\
\cline { 2 - 4 } & Anger tow Sanador & 3 & $7.70 \%$ \\
\cline { 2 - 4 } & Disgust tow Sanador & 1 & $2.60 \%$ \\
\cline { 2 - 4 } & Disgust tow Ro medical system & 3 & $7.70 \%$ \\
\cline { 2 - 4 } & Disgust tow Ro society & 1 & $2.60 \%$ \\
\hline Attribution-independent emotions & Sympathy & 3 & $7.70 \%$ \\
\hline
\end{tabular}

Romanian society ("Do we need a lame press release to get furious? Don't we know what kills our children in the Romanian hospital? Yes, we do know. (...)", our transl.)

As mentioned above, these four Facebook posts triggered 179 comments. As observed in Table III, negative strong emotions prevail, sympathy being expressed only six times. Contempt and disgust are also the most salient emotions. Following the four contempt inducing Facebook posts, commenters clearly mentioned their disregard toward the Sanador hospital's lack of compassion and toward the surgeon's improper statement. The online users' contempt was associated to the pessimistic feelings about the Sanador Hospital's possibility of betterment. The online users' lack of trust in Sanador Hospital's improvement is expressed in a twofold way:

- through emotionally loaded adjectives which clearly highlight an explicit labeling of doctors as "more cynical than the scumbags from our politics" (male, our transl.) or "imbeciles and arrogant" (female, our transl.);

- through a negative presentation of their medical services: "Sanador does not assume anything. On the contrary, they charge you a lot of money. Zero humanity" (female, our transl.) or "Sanador could be nothing more than a polyclinic providing disease prevention services, it could be ABSOLUTELY not a hospital." (female, our transl.)

Disgust toward Sanador and the doctors who performed the surgery was associated to a fear-driven avoidance regarding this hospital: "A very unprofessional hospital. I had an unpleasant experience in the past. I do not recommend it." (female, our transl.) or "To go to a private hospital, to pay a lot of money for a surgery and to take your child in four wooden pieces, how would you call this?" (female, our transl.). 
Table 3. Frequencies of online users' emotions on Facebook (generated by QDA miner 5.0)

\begin{tabular}{|c|c|c|c|}
\hline \multicolumn{2}{|c|}{ Emotions } & \multirow{2}{*}{$\begin{array}{c}\text { Frequency } \\
3\end{array}$} & \multirow{2}{*}{$\begin{array}{c}\% \\
1.20 \%\end{array}$} \\
\hline & Fear & & \\
\hline & Contempt tow Sanador & 40 & $16.20 \%$ \\
\hline & Contempt tow doctors - CD & 10 & $4.00 \%$ \\
\hline & Contempt tow Ro medical system & 11 & $4.50 \%$ \\
\hline & Contempt tow Ro society & 6 & $2.40 \%$ \\
\hline & Contempt tow online user & 4 & $1.60 \%$ \\
\hline & Contempt tow mass-media & 2 & $0.80 \%$ \\
\hline \multirow[t]{8}{*}{ Attribution-dependent emotions } & Anger tow Sanador & 1 & $0.40 \%$ \\
\hline & Anger tow doctors - CD & 1 & $0.40 \%$ \\
\hline & Anger tow online user & 13 & $5.30 \%$ \\
\hline & Disgust tow Sanador & 22 & $8.90 \%$ \\
\hline & Disgust tow doctors - CD & 7 & $2.80 \%$ \\
\hline & Disgust tow Ro medical system & 8 & $3.20 \%$ \\
\hline & Disgust tow Ro society & 1 & $0.40 \%$ \\
\hline & Disgust tow online user & 2 & $0.80 \%$ \\
\hline Attribution-independent emotions & Sympathy & 6 & $2.40 \%$ \\
\hline
\end{tabular}

Besides the salience of contempt and disgust toward Sanador and the doctors responsible for the child's death, these two negative emotions were also related to two different themes:

- corruption and collapse of the Romanian medical system. The polarization between public and private hospitals was used to provide a contrast between a public medical care system where doctors are accused of "(...) disgustingly consulting their patients" (female, our transl.) and a private medical care system where the financial benefits were considered to determine the same doctors to be more willing to consult their patients. Alongside this discussion about the two types of Romanian medical systems, some online users brought up the topic about the profession of being a doctor which should not be restricted to financial matters: "A doctor should be a doctor. Whether they work in a tent in an African village, in Gherla or at Los Angeles. It is a vocational profession. If one does not have this vocation, one should not become a doctor." (female, our transl.)

- revolt against the so-called online specialists. Two different strands of discussions were brought up: criticizing an organization before the completion of an investigation and the labeling of a medical procedure. Dan Negru, one of the influencers, was accused of "throwing stones before the hospital provided any further details" (female, our transl.). This comment triggered angry reactions toward the online user who was blamed for not grasping the reality of a 
child's death. Dan Negru himself commented and justified his post by making a difference between the real crisis situation caused by the Sanador surgeons and the crisis communication management: "Could you please pay attention? I did not say anything about the medical procedure, I have no idea what happened there. It is not my field. But I think that I am more or less good at public relations" (Dan Negru, our transl.). The labeling of the inguinal hernia surgery by one online user as a minor surgical procedure stirred a lot of comments for and against the difficulty of this type of surgery. The biased opinions reflected either various types of medical procedures (from minor ones to difficult ones) or various acts which could be considered commonplace things (online judgment on others). One online user's comment is relevant for this anger toward commenters: "I do hope that none of the «Facebook specialists» around here, ad-hoc judges or professionals, would go through something minor and would, because of this commonplace thing, reach that place where only God could save them (...)" (male, our transl.).

\section{Discussion and conclusion}

The Sanador Hospital case shows the social media power of online users especially when the organization adopts the online silence strategy. The Sanador hospital did not learn one important lesson from effective social media crisis communication, namely to exploit social media's potential by creating dialogue (Eriksson, $2018,531)$. The hospital's lack of online engagement led to online users' various viewpoints by re-framing the crisis situation (the death of a child after a surgery at the Sanador Hospital).

Starting from the social-mediated crisis communication (SMCC) model, we emphasized the importance of a typology of online key publics, either as influential creators or as followers depending on the online activity of posting or of commenting. But the refining of the SMCC model (Mak, Song, 2019) should be taken into account since a social-mediated crisis is a multifaceted situation and online users bring up topics of their own interests. Thus, the typology of online key publics should include the category self-involvement for both influential creators and followers. As the analysis showed, online users (both public persons and commenters) re-framed the crisis situation at the Sanador Hospital, bringing forth secondary topics such as personal experiences, a decaying and corrupted Romanian medical system, or the lethargy of the Romanian society.

Since the internal crisis situation at the Sanador Hospital implied the death of a child, emotional responses played an important role on how influencers and followers engaged in this crisis. Results indicated that the four social media creators' posts affected the social media followers' emotions. The four influential social media creators acted as credible information sources since they positioned them- 
selves as communication specialists and criticized the Sanador inefficient crisis communication management. For both categories of key publics, contempt and disgust were the most salient negative emotions. Since contempt and disgust are attribution-dependent emotions, we may infer that most social media influencers and followers tend to attribute a macro-responsibility (Romanian medical system), a mezzo-responsibility (Sanador Hospital), and a micro-responsibility (surgeons responsible for the child's death).

One important finding is the presence of anger within the followers' comments, but the recipients of this attribution-dependent emotion are online users. The discussion among the self-involved followers focused on the 'know-it-all Facebook specialists,' on the polarization between who was entitled or not to provide an online opinion. Moreover, despite this tragedy, it was interesting to observe that sympathy, an attribution-independent emotion, was not as prevalent as expected. Some influencers and followers expressed their compassion with the family and other online users who went through bad experiences at the Sanador Hospital, but most of them focused on expressing their revolt against the arrogance and lack of empathy of the hospital, or against a corrupted and collapsing medical system.

This study shows that an analysis of the online key publics in crisis situations should take into account: (a) two categories of key publics (influencers and followers); (b) an issue refinement of the messages as posts or as comments (crisis related information versus secondary topics where self-involvement prevails); (c) influencers' and followers' emotional responses. The analysis of the key publics' emotional responses highlighted that trustworthy, expertise, and similarity as main elements of the credibility of Romanian social media influencers were also found in this study on crisis communication. But unlike previous studies (Balaban, Mustățea, 2019, 41), these three elements could be associated with followers as well. The four influencers acted as trustworthy experts in public relations whose posts triggered various comments, but commenters also acted as users who went through similar situations.

This study has two limitations: a) the scope of the study is limited to one crisis situation and a broadening of the study cases could provide a more encompassing view over the Romanian medical system; $b$ ) content analysis provides insights into the usage of various roles by key publics or into the frequency of emotional responses, but experiments may investigate the influencers' emotional impact upon followers. Despite these limitations, we believe that this study is important for the de-westernizing of the social-mediated crisis communication (SMCC) research in a global context and for providing a typology of influencers and followers in crisis situations. 


\section{References}

1. Austin, L.L., Liu, B. F., \& Jin, Y. (2012). How audiences seek out crisis information: Exploring the social-mediated crisis communication model. Fournal of Applied Communication Research, 40(2), 188-207. doi: 10.1080/00909882.2012.654498.

2. Austin, L., \& Jin, Y. (2017). Social media and crisis communication: Explicating the social-mediated crisis communication model. In A. Dudo, LA Kahlor (Eds.). Strategic communication. New agendas in communication (pp. 163-186). Routledge.

3. Balaban, D., \& Mustățea, M. (2019). Users' perspective on the credibility of social media influencers in Romania and Germany. Romanian fournal of Communication and Public Relations. 21, 1(46), 31-46.

4. Cheng, Y., \& Cameron, G.T. (2017). The status of the social mediated crisis communication (SMCC) research: An analysis of published articles in 2002-2014. In L.L. Austin, Y. Jin (Eds.). Social media and crisis communication (pp. 9-20). Routledge.

5. Choi, Y., \& Lin, Y. H. (2009). Consumer responses to Mattel product recalls posted on online bulletin boards: Exploring two types of emotion. Fournal of Public Relations Research, 21(2), 198-207. doi: 10.1080/10627260802557506.

6. Coombs, W. T. (2007). Protecting organization reputations during a crisis: The development and application of situational crisis communication theory. Corporate Reputation Review, 10(3), 163-176. doi: 10.1057/palgrave.crr.1550049.

7. Coombs, W. T., \& Holladay, J. S. (2012). The paracrisis: The challenges created by publicly managing crisis prevention. Public Relations Review, 38(3), 408-415. doi: 10.1016/j. pubrev.2012.04.004.

8. Eriksson, M. (2018). Lessons for crisis communication on social media: A systematic review of what research tells the practice. International fournal of Strategic Communication, 12(5), 526-551. doi: 10.1080/1553118X.2018.1510405.

9. Freberg, K., Graham, K., McGaughey, K., \& Freberg, L.A. (2011).Who are the social media influencers? A study of public perceptions of personality. Public Relations Review, 37(1), 90-92. doi: 10.1016/j.pubrev.2010.11.001.

10. Jin, Y, \& Pang, A. (2010). Future directions of crisis communication research: Emotions in crisis - the next frontier. In W. T. Coombs, \& S. J. Holladay (Eds.). The handbook of crisis communication (pp. 677-682). Chichester, UK: John Wiley \& Sons.

11. Jin, Y., Liu, B. F., \& Austin, L. L. (2014). Examining the Role of Social Media in Effective Crisis Management: The Effects of Crisis Origin, Information Form, and Source on Publics' Crisis Responses. Communication Research, 41(1), 74-94. doi: 10.1177/0093650211423918.

12. Liu, B. F., Jin, Y., Briones, R. L., \& Kuch, B. (2012). Managing turbulence online: Evaluating the blog-mediated crisis communication model with the American Red Cross. Fournal of Public Relations Research, 24, 353-370. doi: 10.1080/1062726X.2012.689901.

13. Mak, A. K. Y., \& Song, A. O. (2019). Revisiting social-mediated crisis communication model: The Lancôme regenerative crisis after the Hong Kong Umbrella Movement. Public Relation Review, in press, available online 22 July 2019. doi:10.1016/j.pubrev.2019.101812.

14. Miceli, M., \& Castelfranchi, C. (2018). Contempt and disgust: The emotions of disrespect. Journal of the Theory of Social Behavior, 48(2), 205-229. doi: 10.1111/jtsb.12159. 